\title{
On the Nature and Significance of Mercury Inhibition of Invertase from Saccharomyces cerevisiae
}

\author{
By D. K. KIDBY \\ Department of Microbiology, College of Biological Science, \\ University of Guelph, Ontario, Canada
}

(Received I8 April 1974; revised 29 May 1974)

\begin{abstract}
SUMMARY
The mechanism of mercury inhibition of invertase, $\beta$-D-fructofuranosidefructohydrolase EC. 3.2.I.26, from Saccharomyces cerevisiae, both in vitro and in vivo, is similar with respect to effective mercury concentrations. Contrary to previous reports on invertase from $S$. cerevisiae, the enzyme in this study does not dimerize in the presence of mercury nor does it exhibit competitive inhibition kinetics. A further apparent inconsistency with previous work is the marked dependency of inhibition upon $\mathrm{pH}$ and anion concentrations.
\end{abstract}

\section{INTRODUCTION}

The interaction of invertase with mercury has been examined in attempts to characterize invertase isozymes (Hoshino \& Momose, 1966), to determine the mechanism of the inhibition of invertase activity (Myrback, 1957), to effect purification of the enzyme (Berggren, 1967), and to use it as a sensitive assay for mercury (Mealor \& Townshend, 1968). That mercury is a potent inhibitor of yeast invertase is well known (see Neuberg \& Mandle, 1950). However, the mechanism of this interaction, and indeed those involving heavy metals in general, is not well understood. Nor is there much understanding of the relationship of the in vitro observations to the inhibition of enzymes in vivo.

Mercury, as mercuric ion, appears to be a reversible competitive inhibitor, which shows no distinct dependence upon $\mathrm{pH}$ or counter-ion concentration and does not completely inactivate the enzyme (Myrback, 1957). The enzyme may form a dimer in the presence of mercuric ion (Berggren, 1967). Concerning possible effects of mercury on this enzyme in vivo, Passow, Rothstein \& Clarkson (196I) suggested that exo-enzymes could be susceptible targets for heavy metals. That invertase should be particularly sensitive is suggested by its apparently freely soluble state although still entrapped within the yeast wall (Kidby \& Davies, 1970a; Sommer \& Lewis, 1971). However, even if inhibition is observed for the enzyme when in vitro, it is essential that its structure should not have changed. This is a point which must be considered in the light of the demonstration that the composition of the purified enzyme is, at least in some cases, a function of the manner in which it is prepared (Andersen \& Jorgensen, 1969). This paper bears upon these aspects of our current understanding.

\section{METHODS}

Organism and enzyme release. Two $\mathrm{kg}$ of dried Saccharomyces cerevisiae (YSC; Sigma) was autolysed at pH 6.0 for 6 days in the presence of toluene at $30^{\circ} \mathrm{C}$ as described by Berggren (1967). The autolysate supernatant was collected by centrifuging. Comparison of 
the enzyme, by electrofocusing and by exclusion chromatography, with the enzyme released by sonication (Kidby, unpublished) indicated no adverse effects of the prolonged autolysis, which substantiates the findings of Berggren (1967).

Protein was determined using a Folin-Ciocalteau reagent (Legget-Bailey, 1967) with lysozyme as a standard. Carbohydrate was determined by a phenol/sulphuric acid method (Dubois et al. 1956) with glucose as standard. Invertase activity was measured as previously described (Kidby \& Davies, I $970 b$ ). Electrophoretic homogeneity was checked by a disc-gel procedure using borate buffer (Kidby \& Davies, 1970 $a$ ) and also by a gradient gel method (Kidby, 1970).

Purification of invertase. At each purification step the enzyme was characterized by exclusion chromatography on a $70 \times 2.5 \mathrm{~cm}$ Sephadex G-200 column containing $0.05 \mathrm{M}-\mathrm{NaH}_{2} \mathrm{PO}_{4}$ buffer at $\mathrm{pH} 7.0$ and $0.01 \% \mathrm{NaN}_{3}$ at $10{ }^{\circ} \mathrm{C}$.

The crude enzyme solution, $6 \cdot 41$, was concentrated to $700 \mathrm{ml}$ by filtering through dialysis tubing at reduced pressure and then adjusted to $\mathrm{pH} 5.0$ with glacial acetic acid. Carbowax 4000 (Analab Co. Inc., U.S.A.) was added to a final concentration of $22 \%(w / v)$ and the mixture stirred for $3 \mathrm{~h}$ at $25^{\circ} \mathrm{C}$. The lower Carbowax phase, $126 \mathrm{ml}$, was removed, and half of it was adjusted to $\mathrm{pH} 8.0$ with tris buffer, made to $100 \mathrm{ml}$ with water to reduce viscosity and chromatographed on a $40 \times 5.0 \mathrm{~cm}$ DEAE-Sephadex column at $4{ }^{\circ} \mathrm{C}$. The column was first eluted with $0 . \mathrm{I} \mathrm{M}$-tris buffer at $\mathrm{pH} 8.0$ and the invertase then eluted with $0 . \mathrm{I}$ M-tris buffer at $\mathrm{pH} 7.0$ containing a linear $\mathrm{NaCl}$ gradient. Invertase was eluted in a single peak at $50 \mu \mathrm{g}$ atoms chloride $/ \mathrm{ml}$. The eluted enzyme fractions were combined, dialysed and concentrated simultaneously in dialysis tubing against water, then freeze-dried. Although there was good correspondence of activity, protein and carbohydrate peaks in the eluted fractions, these are not criteria of purity. The purity of the preparation was therefore assessed by exclusion chromatography, analytical ultracentrifugation (see below), disc electrophoresis and substrate specificity. This preparation, used in all subsequent procedures, contained $95 \%$ carbohydrate and had a specific activity of $912 \mu \mathrm{mol}$ substrate reacted $/ \mathrm{min} / \mathrm{mg}$ protein at pH 5.3 in $0.01 \mathrm{M}$-sodium acetate at $30{ }^{\circ} \mathrm{C}$. The recovery was $43 \%$ of initial activity, $50 \%$ of activity being lost in the DEAE-Sephadex step. Further exclusion chromatography on Sephadex G-200 did not increase specific activity with respect to either protein or carbohydrate. Ammonium sulphate precipitation in certain cases (Andersen \& Jorgensen, 1969) has reduced carbohydrate content in similar high carbohydrate invertase preparations but in the present study this step was quite ineffective.

Analytical ultracentrifugation. The leading half of the activity profile from preparative scale exclusion chromatography on Sephadex G-200 in $0.05 \mathrm{M}-\mathrm{NaH}_{2} \mathrm{PO}_{4}$ buffer, $\mathrm{pH} 7 \cdot 0$, was concentrated on an Amicon XM50 filter to a $\mathrm{I} \cdot 0 \mathrm{~cm}$ absorbance of 0.9 at $280 \mathrm{~nm}$. The leading half of the activity profile was used because this is less likely to be contaminated by an overlapping species, although there was no evidence of contamination. This precaution appeared warranted in the light of our apparent difficulty in demonstrating an effect of mercury on the sedimentation coefficient. Separate samples were dialysed against chromatography buffer either with or without $2 \times 10^{-5} \mathrm{M}^{-} \mathrm{HgCl}_{2}$, or against an enzyme reaction mixture containing sodium acetate and substrate either with or without $\mathrm{HgCl}_{2}$. In two independent comparisons, the sample with added mercury was placed in the reference cell position and directly compared with the sample without mercury, using both absorbance at $280 \mathrm{~nm}$ and Schlieren optics. Runs were performed in analytical cells in a Beckman Model E ultracentrifuge at $201000 \mathrm{~g}$ and $20{ }^{\circ} \mathrm{C}$ for the times indicated.

Enzyme kinetics. Measurements on all substrate concentrations were performed in triplicate. Curve fitting was carried out according to Wilkinson (I96I). 


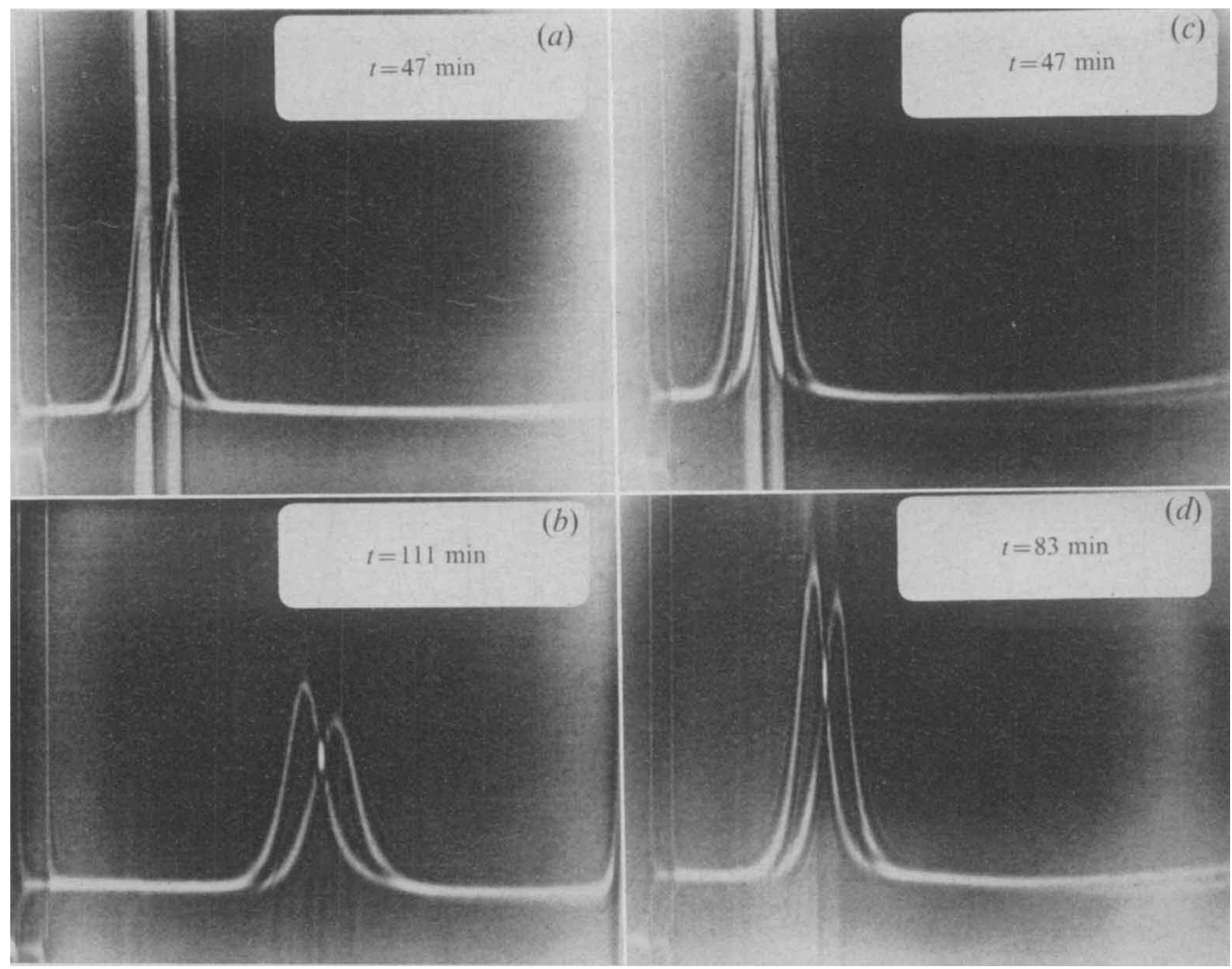

Fig. I. Analytical ultracentrifugation of invertase in the presence of mercury. Migration of invertase in the presence and absence of mercury was followed from 47 to $111 \mathrm{~min}(a$ to $b$ ) in the absence of sucrose and from 47 to $83 \mathrm{~min}(c$ to $d)$ in the presence of sucrose. The reference cell, with samples containing $2 \times 10^{-5} \mathrm{M}-\mathrm{HgCl}_{2}$, has the left-hand meniscus and Schlieren boundary peak in each case.

In vivo enzyme activity measurement. Invertase activity was measured, in the manner described, in the presence of $0.01 \mathrm{M}-\mathrm{NaF}$ which prevents metabolism of the reaction products, glucose and fructose. This procedure is completely satisfactory provided that sufficiently few yeast cells are present in the reaction mixture to preclude interference with absorbance measurements by light scattering.

Reagents. Analytical-grade reagents and glass-distilled water were used unless otherwise indicated.

\section{RESULTS}

Analytical ultracentrifugation of invertase in the presence of mercury

If, as indicated by Berggren (1967), invertase dimerizes in the presence of mercury then this should be detectable as an altered sedimentation coefficient. Purified invertase, however, had the same sedimentation coefficient of 4.0 both in the presence and absence of mercuric chloride (Fig. I $a, b$ ). In a further experiment the enzyme was maintained throughout centrifuging under conditions where inhibition by mercury could be directly demonstrated, but this too yielded no evidence of an invertase dimer (Fig. $\mathrm{x} c, b$ ). 
Table I. Kinetics of invertase inhibition by mercuric chloride

$\begin{array}{ccc}\text { Mercury (M) } & K_{m} \pm \text { S.E. } & V_{\max } \pm \text { S.E. } \\ 0 & 0.0259 \pm 0.0002 & 912.0 \pm 9.3 \\ 2.0 \times 10^{-7} & 0.0267 \pm 0.0015 & 209.0 \pm 4.4\end{array}$

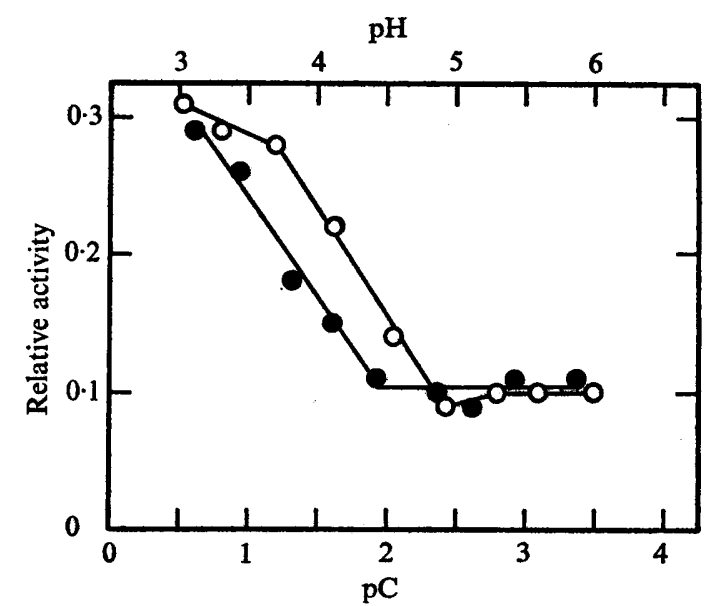

Fig. 2

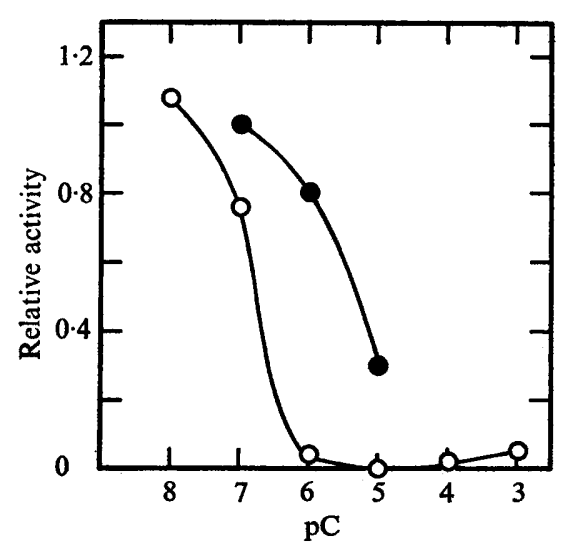

Fig. 3

Fig. 2. Dependency of mercury inhibition on pH and buffer anion concentration. Activity measurements are for $1.0 \times 10^{-6} \mathrm{M}^{-} \mathrm{HgCl}_{2}$ relative to activity at the particular $\mathrm{pH}$ or anion concentration in the absence of $\mathrm{HgCl}_{2}$. $\mathrm{O}, \mathrm{pH} ; \mathbf{0}, \mathrm{pC}\left(-\log _{10} \mathrm{M}\right)$ for acetate.

Fig. 3. Relative inhibition by mercuric chloride and methyl mercury. Activities are relative to activity in the absence of added inhibitor. $\mathrm{O}, \mathrm{pC}\left(-\log _{10} \mathrm{M}\right)$ for $\mathrm{HgCl}_{2} ; \boldsymbol{\mathrm { pC }}$ for methyl mercury hydroxide.

\section{Kinetics of invertase inhibition by mercuric chloride}

The inhibition kinetics (Table I) indicate that inhibition is non-competitive, since mercury produces a change in maximum velocity rather than in substrate affinity.

\section{Dependency of mercury inhibition on $\mathrm{pH}$ and buffer anion concentration}

There is first a marked dependency of inhibition upon acetate concentration, followed by a concentration range over which little effect is seen (Fig. 2). The effect of $\mathrm{pH}$ is qualitatively similar (Fig. 2), although for quite different reasons. This point is discussed below.

\section{Relative inhibition by mercuric chloride and methyl mercury}

Although methyl mercury hydroxide is a highly toxic mercury compound, mercuric chloride is much more toxic towards this enzyme (Fig. 3). The apparent activation at $1 \mathrm{IO}^{-8} \mathrm{M}-$ mercuric chloride is reproducible and disappears at ${ }^{10} \mathrm{O}^{-9} \mathrm{M}$.

\section{Substrate specificity}

That the enzyme preparation consisted entirely of the conventional yeast $\beta$-fructofuranosidase was shown by its substrate specificity: sucrose and raffinose were both utilized but cellobiose, lactose, maltose and melezitose were not. 


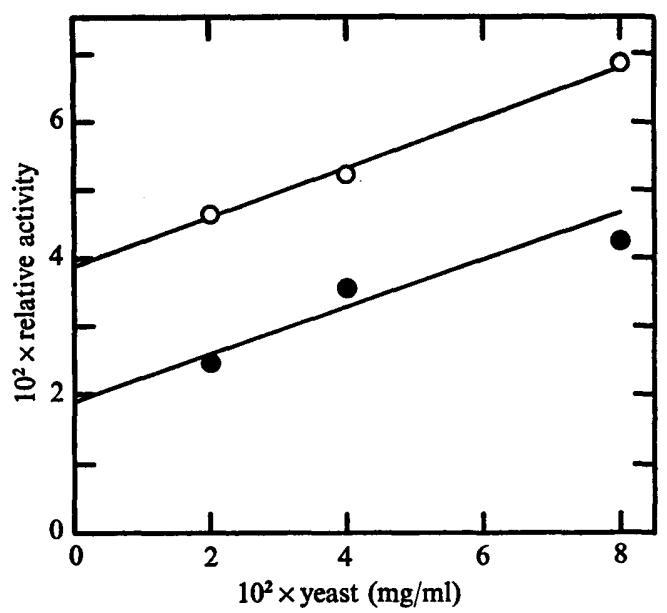

Fig. 4. Comparison of invertase inhibition in vitro and in vivo. Measurement of activity in whole cells was performed as described in Methods. $O, \mathrm{HgCl}_{2}$ at $1 \cdot 0 \times 10^{-6} \mathrm{M} ; 0$, at $1 \cdot 0 \times 10^{-5} \mathrm{M}$. The means of triplicate values are plotted. The intercepts at zero cell concentration are extrapolations.

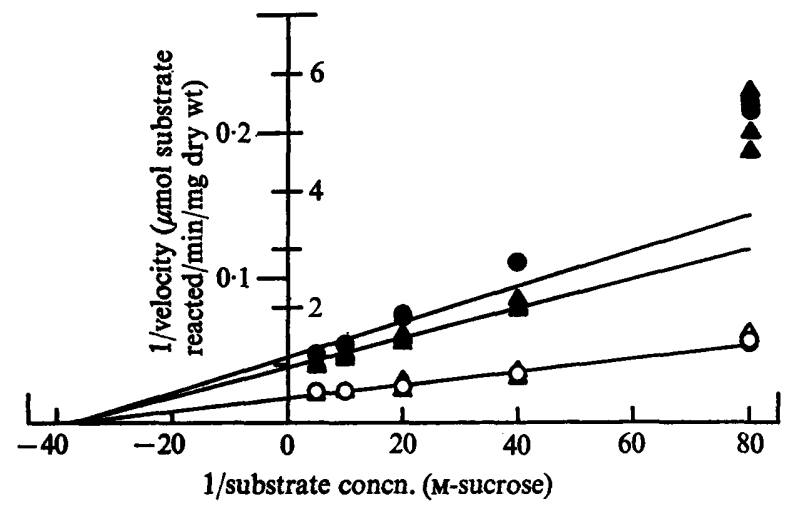

Fig. 5. Kinetics of invertase inhibition by mercuric chloride in vitro and in vivo. Left-hand ordinate scale: enzyme in vitro. Right-hand ordinate scale: enzyme in vivo. Enzyme in vivo is $0.02 \mathrm{mg}$ dry wt of enzyme $/ \mathrm{ml}$. All assays were performed in the presence of $0.01 \mathrm{M}-\mathrm{NaF}$ in $0.01 \mathrm{M}$-sodium acetate at $\mathrm{pH} 5.30$ and, where present, $\mathrm{HgCl}_{2}$ at $2.0 \times 10^{-7} \mathrm{M}$. $\triangle$, Enzyme in vivo with $\mathrm{HgCl}_{2} ; \triangle$, without $\mathrm{HgCl}_{2}$. 0 , Enzyme in vitro with $\mathrm{HgCl}_{2} ; \mathrm{O}$, without $\mathrm{HgCl}_{2}$.

\section{Comparison of invertase inhibition in vitro and in vivo}

The results of experiments with whole yeast (Fig. 4) indicate that the enzyme in vivo shares the susceptibility of the purified enzyme to mercuric chloride, with its Michaelis constant matching that of the purified enzyme (Fig. 5). Apparently, mixed kinetics occur for both the enzyme in vivo and the enzyme in vitro when mercury is added (Fig. 5). Mercury might induce a co-operativity or 'pseudo-allosteric' condition of this enzyme although such a state is without precedent in the inhibition of enzymes by heavy metals. The effect is reproducible and does not reflect an inability to measure the reaction product accurately at low reaction rates. 


\section{DISCUSSION}

The yeast invertase investigated in this study does not share some of the characteristics of yeast invertase investigated by others. Unlike Berggren (1967), we have failed to observe, by either exclusion chromatography or analytical ultracentrifugation, dimer formation in the presence of mercury. However, the enzyme encountered in the present study may fail to dimerize because of the high carbohydrate content which is bound strongly to the protein moiety as indicated by the very low sedimentation coefficients, poor stainability with amidoblack and failure to precipitate any protein in saturated ammonium sulphate. Other instances of invertase with a high carbohydrate content are known (Andersen \& Jorgensen, I969). However, on the basis of exclusion chromatography, analytical ultracentrifugation, disc electrophoresis and substrate specificity, the present enzyme preparation is as homogeneous as any external yeast invertase yet prepared.

The nature of the inhibition of invertase by mercury is also different from that observed previously (Myrback, I957) since the pH dependence is marked and the kinetics are noncompetitive. Mercury and other group II metals are likely to be associated with amino and imidazole groups, so a pH dependence over the range examined is not surprising. The $\mathrm{pH}$ dependence over this range might, at first sight, suggest that a thiol group is not involved, but could be due to a mass action effect from a low $\mathrm{pH}$ on the equilibrium position of a mercaptide-forming reaction:

$$
\mathrm{R}-\mathrm{SH}+\mathrm{HgCl}_{2} \rightleftharpoons \mathrm{R}-\mathrm{S}-\mathrm{HgCl}+\mathrm{H}^{+}+\mathrm{Cl}^{-} \text {. }
$$

To some extent, acetate ions, the buffer used in this work, will also be involved in the above equilibrium because of their association with mercury, but the point made is still valid. At a constant $\mathrm{pH}$, a similar dependence upon acetate ions would be expected and this was indeed observed. The activation of invertase by sub-inhibitory concentrations of mercury may be a Schultz-Arndt Rule phenomenon, as is the case for invertase and silver (Passow et al. 196I).

The author is indebted to Joan Mathers for excellent technical assistance, to Dr R. J. Douglas for performing the analytical ultracentrifugation, to Jeannie Irvin for assistance with enzyme kinetics, and the National Research Council of Canada for financial support.

\section{REFERENCES}

Andersen, B. \& Jorgensen, O. S. (1969). Purification of external invertase from brewer's yeast. Acta chemica scandinavica $23,2270-2276$.

BergGren, B. (1967). Studies on yeast $\beta$-fructofuranosidase (invertase). XXIII. Studies on the heterogeneity of the enzyme and its liberation from the yeast. Arkiv för kemi 29, I 1 7-126.

Dubois, M., Giles, K. A., Hamilton, J. K., Rebers, P. A. \& Smith, F. (1956). Colorimetric method for determination of sugars and related substances. Analytical Chemistry 28, 350-356.

Hoshino, J. \& Momose, A. (1966). Comparative studies on the two forms of yeast invertase. Journal for General and Applied Microbiology r2, 163-177.

KIDBY, D. K. (1970). A simple gradient maker and its application to small polyacrylamide gel columns. Analytical Biochemistry 34, 478-484.

KIDBY, D. K. \& DAVIES, R. (1970a). Invertase and disulphide bridges in the yeast wall. Journal of General Microbiology 61, 327-333.

KIDBY, D. K. \& DAviEs, R. (1970 $b$ ). Thiol induced release of invertase from cell walls of Saccharomyces fragilis. Biochimica et biophysica acta 201, 261-266.

Leggett-Bailey, J. (1967). Techniques in Protein Chemistry, 2nd edn, pp. 340-341. Amsterdam: Elsevier.

MeAlor, D. \& ToWnshend, A. (I968). Applications of enzyme-catalyzed reactions in trace analysis. I. Determination of mercury and silver by their inhibition of invertase. Talanta $13,747-758$. 
MYrbACK, K. (1957). Inhibition of yeast invertase (saccharase) by metal ions. V. Inhibition by mercury compounds. Arkiv för kemi Ir, 471-479.

Neuberg, C. \& MANDL, I. (1950). Invertase. In, The Enzymes, vol. I, pp. 527-549. Edited by J. B. Sumner and K. Myrback. New York: Academic Press.

Passow, H., Rothstein, A. \& Clarkson, T. W. (1961). The general pharmacology of the heavy metals. Pharmacological Reviews 13, 185-224.

SOMMER, A. \& LEWIS, M. J. (197I). Effect of dithiothreitol and yeast: sphaeroplast formation and invertase release. Journal of General Microbiology 68, 327-335.

Wilkinson, G. N. (196I). Statistical estimations in enzyme kinetics. Biochemical Journal 80, 324-332. 